\title{
Formation of the Model for Inclusion of People with Disabilities in the Educational Process of the University
}

\author{
Natalia Baigulova \\ $\mathrm{PhD}$, Assistant Professor of \\ the Department of Social Pedagogy \\ Tomsk State Pedagogical \\ University \\ Tomsk, Russia \\ E-mail: baigulova nat@t- \\ sk.ru
}

\author{
Lyudmila Demina \\ $\mathrm{PhD}$, Assistant Professor of \\ the Department of Social Pedagogy \\ Tomsk State Pedagogical \\ University \\ Tomsk, Russia \\ E-mail: lyud 2@mail.ru
}

\author{
Natalia Medova \\ $\mathrm{PhD}$, Assistant Professor, \\ Head of the Department of \\ Defectology \\ Tomsk State Pedagogical \\ University \\ Tomsk, Russia \\ E-mail: medov@sibmail.com
}

\begin{abstract}
This article deals with the problem of including people with disabilities in the educational process of the university. The authors summarize the existing domestic and foreign experience of solving this problem, and propose their own model of adaptation of people with special educational needs at the stage of preparation for admission and the first year at the Pedagogical University. The presented model is based on the experience of the leading universities of the Russian Federation, and takes into account the direction and potential of the institution, which includes key activities that increase the accessibility of higher education for people of this category, ensuring their further professionalization.
\end{abstract}

Keywords - people with disabilities, educational process, higher education institution, professional tests, inclusive education.

\section{INTRODUCTION}

In modern pedagogical science and practice, active work is carried out to find solutions to the problems of removing the social isolation of people with disabilities (PWD), creating conditions for obtaining higher professional education and, consequently, successful career, social adaptation, and development throughout life. At the same time, analysis of the world practice (by the examples of Serbia, Scotland, England, Slovenia and the Czech Republic) shows that scientists are developing ways to prepare the educational environment of higher education institutions for inclusion of PWD in the educational process (not only the material and technical aspect, but also the training of all participants in the inclusive process, including students and teachers) [6-12].

In the Russian Federation, the use of a systematic approach to solving this problem is becoming a trend [4-5]. According to the results of the all-Russian comprehensive monitoring of the accessibility of higher education for disabled people and PWD, conducted by the Public Chamber of the Russian Federation, only every 33rd disabled person $(3.07 \%)$ under the age of 30 becomes a student, while every 5 th person of the same age without health restrictions enters the university. Only $0.38 \%$ of students have disabilities. And $25 \%$ to $63 \%$ of them do not complete their studies.
The procedure for settling the issues of obtaining vocational education (higher education) by disabled people and PWD in the regional legislation is a separate issue of the legal regulation of the education sphere and is now very relevant. For example, in the Republic of Bashkortostan it is determined that when receiving education, students with disabilities are provided with special textbooks and teaching aids, other educational literature, as well as services of sign language interpreters and typhus translators. And everything is free of charge. In some regions of the Russian Federation (Moscow, Samara, Arkhangelsk, the Republic of Karelia, the Komi Republic, Perm Krai, Tomsk Oblast), inclusive approach to the education is being implemented: there are methodological developments, and certain psychological and pedagogical experience is accumulated. In these regions, a significant number of universities not only have accumulated experience of teaching students with disorders of various types, but also develop their own model of inclusive practice. In recent years, the problem of inclusion in higher education is also being actively developed at the Institute of Psychology and Education of the Kazan Federal University. Efforts are applied to both research and training of the personnel for inclusive education practice, and steps are being taken to provide practical psychological support for educational inclusion in the university itself. Several scientific and practical conferences conducted on the basis of the Institute of Psychology and Education had subjects such as various aspects of teaching students with disabilities in higher education [3-5].

Generalization of domestic and foreign experience allows us to conclude that the main goal of developing our model of inclusion of PWD in the educational process of a university is to provide the most favorable conditions for the harmonious development, self-realization and socialization of students with disabilities. Its most important tasks should be: psychological, logistic, and informational support of the educational process. In combination, it should create an accessible educational environment. To ensure the quality of education for PWD, the following characteristics of the educational environment will be important: the responsibility to the student, the orientation of education to the combination of the social needs of graduates themselves and the needs of 
society, the rehabilitation component of the educational environment.

Identifying main directions and developing specific activities (both within and outside of individual program), so they become integral part of university's social policies, is one of key factors in the development of the PWD inclusion model. In addition, normative acts defining the rights of disabled people in Russia and internationally take an equally important part in modeling the accessible educational environment. The latest of such acts declare exclusion of discrimination, and equality of opportunity for inclusive education. Effective realization of disabled students' right for inclusive education requires not only maintaining accessible environment, but also special training of the faculty.

Coordination of the support of vocational education for PWD should be carried out by scientific and methodological regional centers, and a significant role in improving the quality of such education can be played by a system of social partnership that unites employers, employees, employment service, students and their parents, educational authorities, public organizations for PWD and universities.

\section{RESULTS AND DISCUSSION}

Educational environment's structural components, as identified by E.V. Petrakov:

- space-object component (premises, equipment and materials; logistic and aesthetic implementation of classes)

- $\quad$ social component (space of interpersonal interaction between students, teachers, psychologists, administration, and types of this interaction)

- methodological (reflexive assessment of psychological and didactic grounds for determining goals, content and methods of teaching, including based off authorial educational programs)

Building upon this idea, one should take into account opinions of philosophers on the possibility of training PWD [1].

According to the opinion of O.T. Loiko, the problem of the self-identification of human and of humankind as a whole acquires an ever-increasing connection with the we-being that can not exist outside of social memory, and the idea of the humanity obliges us to assimilate such a perspective, through which we, in turn, would observe ourselves as members of some inclusive community by means of understanding of the meanings that make up its content, and contribute towards establishment of understanding among participants in the communicative process within a given society [1]. Thus, the identified problem of training PWD is indicated from the following points:

- necessity of identification of the educational environment deficiencies with a goal of developing guidelines for creation of a support model for this category of students;

- creation of a communicative and tolerant environment as the basis for an inclusive community;

- health accounting for students with disabilities as a factor of personal development.
It is important to emphasize that one of the problems identified by the pedagogical university specialists in forming the support model for PWD under the conditions of a higher educational institution is their lack of readiness to receive a profession. This fact is due to the following reasons: concomitant impairments; lack of understanding of the specialty, lack of motivation due to personal immaturity; gaps in knowledge in general subjects; insufficient formation of training skills that are required for training in a college or university; inability to interact in the environment of conditionally-normal people. These facts demonstrate the impossibility of fully implementing both health preservation, and creation of a communicative and tolerant direction.

In addition to the aforesaid, it should be emphasized that the process of mastering a profession challenges students with disabilities with constant trials and professional tests in various types of occupational (in this case pedagogical) activities. Professional test is a specially organized test, a situation simulating the conditions of real professional activity, allowing students to implement a number of trial activities, with subsequent analysis of the results of these actions. What is proposed is using professional test methodology in the model of including PWD in the educational process. At the preparatory stage for university studies at the undergraduate level, PWD can take trials in order to gain a deeper understanding of their own capabilities and the specifics of their future profession [2]. And at the preparatory stage for the master's level they include trials for future students as mentors, since master's degree gives the opportunity to occupy leadership positions in future [1].

In view of the foregoing, it can be concluded that the prerequisite for the normal functioning of the model for supporting people with disabilities is that the participants in the educational process take into account the simplest rules of inclusive interaction. At the first stage of the model implementation, the problem of inclusive interaction in the communicative aspect arises urgently (most often it reduces only to the availability of information and communication technologies). If the university has these technologies, the issue of inclusive communication is considered to be fully resolved. Volunteer support take place in different forms throughout the entire period of education. But the most important inclusion before entering the institution is acquaintance with the infrastructure and the subject-disciplinary side of professional activity chosen by the entrant with disabilities. The Resource Training and Methodological Center for accompanying PWD analyzes the deficiencies in the availability of information in accordance with the program material.

At the second stage of the model implementation, the main activity is the definition of the educational route, taking into account the recommendations of the individual program for the rehabilitation of a disabled person, namely: the regime for attending lectures and workshops; the directions of educational activities for which cooperation with the visually impaired care center is needed (submission of the work plan to the department); the need for an assistant proficient with Braille's system and Russian sign language; the possibility of using a dictaphone and audio tutorials from the library's fund (within the 
framework of interdepartmental interaction); the analysis of the training fund on the profile of training and the writing of the plan for the publication (adaptation) of the necessary educational and methodological aids. An important aspect is the peculiarities of the internship of PWD. Resource center of inclusive quasi-professional activity as a functional unit can act as a competency simulator, which is necessary for a student of the category under discussion.

At the third stage of the model implementation, the individual educational route of the PWD in the conditions of the higher educational institution is determined: full inclusion, taking into account the forms of interagency cooperation and volunteer assistance; partial inclusion, taking into account the forms of interagency cooperation and volunteer assistance and the individual mode of attending classes (combination with distance learning).

Thus, training of PWD in the conditions of a higher education institution presupposes the solution of a complex task in which the development of general and professional competencies is combined with medical, psychological and social adaptation and rehabilitation and support that provides accessibility and variability in the education of persons of this category.

\section{CONCLUSION}

The analysis of the theoretical basis for training of PWD, as well as the generalization of domestic and foreign experience in solving the problem of including PWD in the educational process of the university made it possible to identify the prospects and the main components of the formation of a model of affordable higher education for persons of this category. The specificity of the presented model consists in the gradual inclusion of PWD with the obligatory professional testing taking into account the profile of the higher educational institution, and accompanying the student at the stage of adaptation to the educational space of the institution. In the future, further research is planned to pilot the developed model into practice at the Tomsk State Pedagogical University.

\section{REFERENCES}

[1] O.A. Mashkina, O.T. Loiko, "The Cyberspace in relation to the cultural memory," Collection: Proceedings of the 27th International Business Information Management Association Conference - Innovation Management and Education Excellence Vision 2020: From Regional Development Sustainability to Global Economic Growth - Milan, 2016 pp. $68-74$

[2] L.G. Smyshlyaeva, L.S. Demina, G.Y. Titova, E.N. Dudina, "Professional probation as a system-base of acmedirected bachelor training for socially-critical environmental education," Ecology, Environment and Conservation. 2014. - VOL. 20 (Suppl.) - pp.507-514

[3] L.G. Smyshlyaeva, L.S. Demina, I.L. Shelekhov, D.B. Nasonov, O.I. Kravchenko, S.S. Kalinina, "Peer Mentoring as a Professional Test for Trainee Teachers in the Sphere of Deviant Behavior Prevention of Minors," Linguistic and Cultural Studies: Traditions and Innovations Proceedings of the XVIIth International Conference on Linguistic and Cultural Studies (LKTI 2017), October 11-13, 2017, Tomsk, Russia. - pp. 37-43. URL: https://link.springer.com/book/10.1007/978-3-319-67843-6

[4] I. Shelekhov, E. Grebennikova, E. Berestneva, O. Marukhina, "The Interrelationship Between Social Anxiousness and Psychological Defense Mechanisms," Information Technologies in Science, Management, Social Sphere and Medicine (ITSMSSM 2016). - Published by Atlantis Press, 2016. - pp. 490-493. - ISBN (on-line): 978-94-6252196-4. URL : http://www.atlantispress.com/php/pub.php?publication=itsmssm- 16
[5] I. Shelehov, O. Zharkova, I. Dubinina, L. Petrova, G. Belozerova, E. Berestneva, "Systematic Approach as a Methodological Basis for Personal-Oriented Psychological Research," Proceedings of the IV International research conference "Information technologies in Science, Management, Social sphere and Medicine» (ITSMSSM 2017). Published by Atlantis Press, 2017. - pp. 475-480. URL: https://www.atlantis-press.com/search?q=

SYSTEMATIC+APPROACH+AS+A+METHODOLOGICAL+BASIS+ FOR+PERSONAL-ORIENTED+PSYCHOLOGICAL+ RESEARCH \& type $=*$

[6] V. Kantor, "Herzen university: preparing professionals for education and psychological and pedagogical rehabilitation of people with disabilities - traditions, experience, prospects versity: preparing professionals for education and psychological and pedagogical rehabilitation of people with disabilities - traditions, experience, prospects," Sborník konference projektu "Inovace propedeutických disciplín pro studijní obory se speciální pedagogikou.” Olomouc, Unive rzita Palackého, 2013, pp.147-161

[7] M. Ainscow, T. Booth, A. Dyson, P. Farrell, J. Frankham, F. Gallannaugh, A. Howes, R. Smith (2006): Improving schools, developing inclusion. London: Routledge, 2006. - improving the school, developing integration. London: Routledge.

[8] A. Armstrong, D. Armstrong, I. Spandagou (2010): Inclusive education: international policy and practice. London: Sage, 2010. Inclusive Education: International Policy and Practice. London: Sage.

[9] T. Booth, M. Ainscow, "Index for inclusion: developng learning and participaiton in schools. Bristol: Center for Studies on Inclusive Education," Index for inclusion: learning developng and participaiton in schools.Bristol: Center for Studies on Inclusive Education, 2002

[10] B. Dekleva, "Kvalitativno istraživanje u (slovenačkoj) socijalnoj pedagogiji, u S. Ma-cura-Milovanović," Socijalna pedagogija u nastajanju-traženje odgovora na problem društveno isključenih grupa (pp. 145-161). Jagodina: Pedagoški fakultet u Jago-dini, 2010.

[11] L. Florian, M. Rouse, "The inclusive practice project in Scotland," teacher education for inclusive education, Teaching and Teacher Education, 2009. Vol. 25, pp. 594-601.

[12] M.M. Sunchitsa, "Preparation of future teachers for inclusive education in Serbia: current condition and needs," Pedagogy Faculty at Khagodoni, Jagodina Iboja Hera Visoka School of Structural Studios for the Education of the Vапитаačića, Novi Sad Mirjana Kovacevih Basic School, 2011, pp.208-222. 